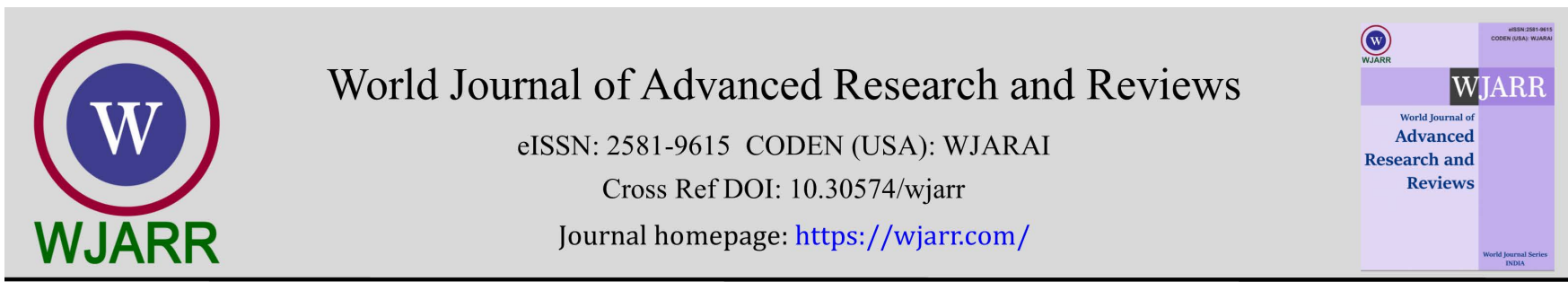

(REview ARTICLE)

\title{
An overview of the solid state fermentation in the production of fungal protease enzymes
}

\author{
Sambo S 1,3, *, Magashi AM 2, Farouq AA ${ }^{3}$ and Hassan SW 4 \\ ${ }^{1}$ Department of Biology, Shehu Shagari College of Education, Sokoto, Nigeria. \\ ${ }^{2}$ Department of Microbiology, Bayero University, Kano, Nigeria. \\ ${ }^{3}$ Department of Microbiology, Usmanu Danfodiyo University, Sokoto, Nigeria. \\ ${ }^{4}$ Department of Biochemistry, Usmanu Danfodiyo University, Sokoto, Nigeria.
}

World Journal of Advanced Research and Reviews, 2021, 09(03), 085-089

Publication history: Received on 23 January 2021; revised on 27 February 2021; accepted on 02 March 2021

Article DOI: https://doi.org/10.30574/wjarr.2021.9.3.0061

\begin{abstract}
Enzymes are among the most important products obtained for human needs through microbial sources. A large number of industrial processes in the area of industrial, environmental and food technology utilize enzymes at some stage or another; Solid State Fermentation (SSF) holds tremendous potential for the production of enzymes, especially in those processes where the crude fermented product may be used directly as the enzyme source. Fungal proteases are used in many industrial processes for the production of foods and metabolites, production of enzymes from fungi offered many advantages which include low cost and high productivity. Hence because of the higher yielding capacity of SSF and the demand for proteases it highly imperative to search for novel microorganisms from possible environment and subject them to SSF for protease investigation to add up to the nation need of the enzymes and boast economy.
\end{abstract}

Keywords: Proteases; Fungi; Solid State Fermentation and Substrates

\section{Introduction}

The process of solid state fermentation for food application is one of the oldest knowledge available to humans. To many communities it is a part of their traditional knowledge to prepare the fermented food [1]. The traditional fermentations such as Koji, Tofu, Miso, sauceges, pickles, ensiling are the extension of the traditional fermentation knowledge exploiting the generally registered as safe (GRAS) strains of fungi and bacteria to carry out the fermentation, the process provide extracellular fungal enzymes and have been the basis to initiate the microbial enzymes production by SSF in industrial environment the Koji process undoubtedly influenced the first production of microbial enzyme by SSF on industrial scale, and the emergence of modern SSF based enzyme industry may be attributed to the entrepreneurship of Jokichi Takamine and later by underkofler's efforts in producing mold bran enzymes for saccharification of grain [2].

Solid state fermentation however as described by Hoda [3] is the one in which micro-organisms secrete the necessary enzymes for degradation of the available substrate molecule in order to meet their nutritional requirements. In this system the fermented mass consist of non-utilized solid substrate containing microbial cells, spores and products for which a number of co-metabolites are formed during the course of fermentation. Equally, SSF is the fermentation in the absence of free liquid and recovery of fermentation products requires it's extraction from the solid fermented medium with a suitable solvent or solutions [4]. A common extract or solvents is distilled or deionized water [5, 6]. Malathi and Chakraborty [7] also used distilled water for extraction of alkaline protease from solid wheat bran fermentation. Tunga et al., [4] also reported that fermented mass was soaked with water for two hours at room temperature to extract proteolytic enzyme. Other extractants have also been used to extract other enzymes e.g. [8] used sodium chloride

\footnotetext{
* Corresponding author: Sambo Sadiya

Department of Biology, Shehu Shagari College of Education, Sokoto, Nigeria.
}

Copyright (C) 2021 Author(s) retain the copyright of this article. This article is published under the terms of the Creative Commons Attribution Liscense 4.0. 
solution, [9] extracted glycoamylace by sodium chloride solution, [10] used 0.002M succinate buffer for lipase and protease, while Castilho [11] extracted pectinases from wheat bran by acetate buffer at PH 4.4. Equally, [3] extracted milk clotting enzyme from wheat bran fermented by Aspergillus oryzae using distilled water, tap water and different salt concentrations of potassium chloride, magnesium chloride, calcium chloride and sodium chloride.

\section{Substrate used for the Production of Enzymes in Solid State Fermentation}

Agro industrial residues are generally considered the best substrates for the SSF processes. A number of such substrates have been employed for the cultivation of microorganisms to produce host of enzymes, some of such substrates includes sugarcane bagasse, wheat bran, rice bran, rice husk, soy - hull, corncobs, banana waste, tea waste, cassava waste, palm oil mill waste, Aspen pulp, Sugar beet pulp, sweat sorghum pulp, apple pomace, peanut meal, coconut oil cake, mustard oil cake, cassava flour, wheat flour, steamed rice, steam pre-treated willow, starch e.t.c. $[12,13,14,15]$. It is interesting to note that although a number of substrates have been employed for culturing different microorganisms, wheat bran has been the preferred choice in most of the studies. Malathi and Chakraborty [7] evaluated a number of carbon sources (bran) for alkaline protease production and reported wheat to be the best for cultivation of A. flavus IMI 32.7634. A strain of A. niger Tieghem 331221 produced large quantities of an extracellular acid protease when grown in SSF system using wheat bran as the sole substrate $[16,17]$ indicated that wheat bran and rice husk supports the maximal growth and $\beta$ - galactosidase production by A. oryzae.

\subsection{Advantages of SSF}

- $\quad$ Process is simple

- $\quad$ Cost effective

- $\quad$ Less effluent release, reduce pollution

- $\quad$ High titers (high product yield)

- $\quad$ Aeration process is easy

- $\quad$ Resembles the natural habitat of some fungi and bacteria

- $\quad$ Easier downstream processing

\subsection{Factors Which Influence SSF}

- Selection of microorganism: - this is one of the key factors that can improve yield of the product. Bacteria yeast and filamentous fungi can be used. Filamentous fungi has shown better result growing in the solid substrate

- Substrate: - substrate also play an important role in determining the growth of microorganisms there by increasing the product yield, substrate is chosen in such a way that it should provide physical support as well as nutrients to the growing culture.

- Process optimization: - this includes the optimization of physico-chemical and biochemical parameters such as size, initial moisture, $\mathrm{pH}$ and pre-treatment of the substrate relative humidity, temperature of in emanation, agitation and accretion, age and size of the inoculum, nutrient supplementation such as N, P and trace element, supplementation of additional carbon source and inducers. Extraction of product and its purification.

- However there are certain problems that are associated with SSF such includes heat transfer which could make it difficult to control the temperature during the fermentation process. Heat is also generative during the metabolic activities of microorganism, since the substrate used has low thermal conductivity heat removal will be slow, and when the heat generated goes beyond certain level it will result in product denaturation and will affect growth of microbes ultimately ending up in reduction in yield and quality of the product.

\subsection{Application of SSF}

The process of solid state fermentation could be employed in the Agro-food industry e.g. for traditional food fermentations e.g. Koji, fermented cheese e.t.c. and also for bioconversion of byproducts e.g. Sugar Pulp Baggasse composting. SSF is also applicable in the Agricultural Industry for biocontrol, bioinsecticides and for plant growth hormones/enhancers equally in industrial fermentation. Solid state fermentation is applicable for production of enzymes, antibiotics, organic acid as well as ethanol. 


\section{Fungi as Source of Proteases}

Fungi are an attractive source of protease owing to the limited space required for their cultivation and their readily susceptibility to genetic manipulation. So, it is a group of great practical and scientific interest to biotechnologists. Many moulds synthesize and excrete large quantities of proteases into the surrounding media. A number of fungal genera such as Aspergillus, Rhizopus, Mucor, Penicillium, Fusarium, Cephalosporium, Conidiobolus and Neurospora are known to produce acid, alkaline and neutral proteases $[18,19,20]$ Those proteases are active over a wide PH (PH4 - 11) and temperature range $\left(30-70^{\circ} \mathrm{C}\right)[21]$.

Acid protease of commercial importance are prepared exclusively from fungal sources and are tentatively divided into two sub-groups by their physiological characteristics i.e. pepsin - like acid proteinases and rennin - like acid proteinases. Pepsin - like acid proteinases have usually been reported in the group of black aspergilla such Aspergillus niger A. awamori, A. usamii and A. saitoi, but also occur in species of pennicilium and Rhizopus [22, 23].

Rennin - like acid protease are produced by strain of Mucormihei, Mucorpusillus and Trametes sanguinea [24]. Studies on milk clotting enzymes have been carried out by many workers because of their industrial importance for use as rennin substitutes in cheese making. For this purpose various fungal strains including species from Aspergillus, Penicillium and Mucor have been exploited [25]. Production of milk clotting enzymes from microbial sources for use as rennin substitutes has been receiving increasing attention, for long time, calf, rennet has been the traditional source of milk clotting enzymes for cheese manufacturing but decreasing worldwide rennet supplies accompanied by ever increasing cheese production and consumption made necessary the utilization of rennet substitutes [26]. The substitutes are used extensively in the dairy industry to produce a suitable curd with good flavor. The specialized nature of the enzyme is due to its specificity in cleaving a single peptide bond in k-casien to generate insoluble para K- casein and C-terminal glycopeptides. [27] Stressed that for alternative sources of milk clotting enzymes of microbial origin, studies were mainly focused on fungal aspartic proteases, although a few reports on bacterial enzymes can be found. Equally [28] added that filamentous fungi are the major producers of microbial aspartic proteases, again it was observed that fungal substitutes for animal proteases includes those from Rhizo mucormiehei [29] Rhizopus oryzae [18] Aspergillus oryzae [30] penicillium oxalicum [31] Amylomyces rouxi and Fussarium subglutinans ([30] among the several microorganisms studied, Rhizomucor miehei and Rhizomucor pusillus have gained industrial acceptance as producers of milk - clotting enzymes [28].

Filamentous fungi are used in many industrial processes for the production of enzymes and metabolites. Among the many advantages offered by the production of enzymes by fungi are low material costs coupled with high productivity, faster production and the ease with which the enzymes can be modified. Further the enzymes being normally extracellular are easily recoverable from the medium [30].

Although, certain rennet preparation are available in market, some from those Thermophilic fungi $R$. mehei and $R$ Pusillus, but their uses for cheese production is limited due to their higher thermal stability and low ratio of milk clotting activity to proteolytic activity which may lead to undesirable changes in the organoleptic quality of the final product. A possible solution to alleviate the technical challenges described is the identification of milk clotting enzyme with enhanced specificity and reduced thermo tolerance, perform a pioneering study of the ability of mesophilic mucor specie strains to secret milk clotting enzymes, where by a collection of 41 strains out of which 28 strains turnout to be active producers of such enzymes, equally [32] proved the production of aspartic proteases from other mesophilic mucor specie strains (Mucor bacilliformis and Mucor circinelloides) which like bovine chymosin have less heat stability than those from Thermophilic fungi, production of milk clotting enzymes with such quality was also reported in penicilium oxacillicum [31] and Nocadiopsis specie by [32].

\section{Function of Rennin and Peptidase (Proteases)}

The function of rennin enzyme is to curdle milk and separate it into semi-solid curds and liquid whey. Curdling of the milk is necessary if the milk is to be retained in the stomach long enough for the milk proteins to be digested properly. Young mammals would drive no benefit from the milk they drink if it passes through the stomach too quickly which is what would happen if it was allowed to remain in its non-curdle state. Due to its importance in curdling milk, rennin enzyme is widely used in the food industry, notably in the production of cheese [33].

Peptide hydrolyzing enzymes (Peptidases) play an important role in food industry, so the peptidase producing organism is used as starters for the production of cheese. The enzymes rennet can be used to catalyse the conversion of casein in milk to para-casein by removing a glycopeptide from the soluble casein. Para-casein a further clot i.e. coagulates in the 
presence of calcium ions to form white, creamy lumps called the curd leaving behind the supernatant called the whey [21]. The major application of peptidases or proteases in diary industry is in cheese manufacturing where the primary function of enzymes is to hydrolyze the specific peptide bond to generate Casein and macro peptides [34]. In general peptidases or proteases have a good number of applications in the food industry e.g degradation of the turbidity complex resulting from protein in fruit juices and alcoholic liquors, improvement of quality of protein rich foods, soy protein hydrolysis, gelatin hydrolysis, casein and whey protein hydrolysis meat protein recovery and meat tenderization [35].

\section{Conclusion}

Today only $20-30 \%$ of the world demand for milk clotting preparation was been covered by calf rennet many successful attempts had been done for producing milk clotting enzymes from other sources such as plants or microorganisms. Various microorganisms are known as producers of rennet substitutes such as Aspergilllus oryzae, Endothia parasitica, Mucor circineloides, Mucor miehei and Rhizomucor pusilluse. Hence because of the higher yielding capacity of SSF and the demand for proteases it highly imperative to search for novel microorganisms from possible environment and subject them to SSF for protease investigation to add up to the nation need of the enzymes and boast economy.

\section{Compliance with ethical standards}

\section{Acknowledgments}

The Authors acknowledge the reviewers efforts for reviewing the manuscripts.

\section{Disclosure of conflict of interest}

Authors declare No conflict of interest for this paper.

\section{References}

[1] Hasseltine CW. Solid state fermentation - part 1 processto Biochemistry July/August 1997; 24-27.

[2] Bennet JW. Aspergillus and Koji; History, practice and molecular bilogy SLM news. 2001; 51: 65-71.

[3] Hoda MA. Extraction of milk clotting enzyme produced by Solid State fermentation of Aspergillus oryzae. Polish journal of Microbiology. 2005; 54(3): 241 - 247.

[4] Tunga R, Banerjee R, Bhattacharyya BC. optimizing some factors affecting protease production under Solid-state fermentation Bioprocess Engineering. 1998; 19: 187-190.

[5] Yano T, Ashida S, Tachiki T Kumajail H, Tochikura T. Development of a soft gel cultivation method Agric Biol Chem. 1993; 55: 379-385.

[6] Gidyal NP, Ramakrishna M, Ionsana BK, Karanth G, Krishnaiah MM. Temperature variation and amyloghycosidase levels at different bed depths in a solid-state fermentation system. Chem. Eng. J. 1993; 57: 17-23.

[7] Malathi S, Chakraborty R. Production of alkaline protease by a new Aspergillusflavus isolated under solid substrate fermentation for use as a depilation agent Applied and Environmental Microbilogy. 1991; 57: 712-716.

[8] Yang SS, Chiu WF. Protease production with starchy agricultural wastes by solid-state fermentation. Microbe. 1987; 283: 86.

[9] Shata MAH. ph.D Thesis Microbiology Cairo University Egypy Sirma Y, Mercelo F, Ulgar G, Yekta G. production of extracellular aspartic protease in submerged fermentation with Muccor Mucedo DMs 809.African Journal of Biotechnology. 2010; 9(38): 6382 - 6386.

[10] Munoz- Rivera CT, Tinixo-rabnic JR, Sanchez S, Farres A. Production of Microbial lipase in a solid-state fermentation system.Biotech.lefl. 1991; 13: 274-280.

[11] Castilho LR, Medonho RA, Alves TI. production of pectinases obtained by solid state fermentation of agroindustrial residue with Aspergillus niger. Bioresources Tecnology. 2000; 71: 45-50.

[12] Mitra P, Chatraverty R, Chendra AL. production of proteolytic enzymes in solid state fermentation system Brazillian journal of science research. 1994; 55: 439-442. 
[13] Pandey A, Ashakumary L, Selverkumar P. World of Microbiol. Biotechnol. 1994; 10: 348-349.

[14] Benjamin S, Pandey A. Acta Biotechnol. 1997; 17: 241-251.

[15] Tegerdy RP, Szackacs G, Sipocz J. AppliedBiochem.Biotechnol. 1996; 57: 563-569.

[16] Chakraborty R, Srinivasan M, Sarkar SK, Raghavap KV. Journal of Microbiology and Biotechnology. 1995; 10: 1730.

[17] Nizamuddin S, Sridevi A, Narasimha ct. production of $\beta$-galactosidase by A oryzae in solid state fermentation African Journal of Biotechnology. 2008; 7(8): 1096-1100.

[18] Karuna J, Ayyanna C. production of Semi - alkaline protease enzyme from Aspergillus Spp. Proceeding of the Minth national convention of chemical engeneers and international symposium on importance of Biotechnology in coming decades Viskh Patnam India. 2008; 8 -11.

[19] Youngquan L, Wengian H. study on sheep port bating with acid protease, Zhonggvopige. 1998; 27: 16-17.

[20] Baoying T, Jianmin C. Selection of acid resistant proteinase - producing strain and its fermentation condition Shipin Yu Fajia Congy. 1998; 24(8): 8- 19.

[21] Sunila D, Hamid, M, Asad - ur - rehman and Ikramu ulr - haq. production of Rennet - like protease by Muccor pusithes throughsubmerged fermentation. Pak J Bot. 2015; 47(3): 1121-1127.

[22] Yang FC, Lin IH. Production of acid protease using thin stillagefrom a rice-sprit distillery by Aspergillus niger. Enzyme Microbial Technol. 1998; 23(6): 397-402.

[23] Haq J, Mukhtar H, Davdis S, Ali S, Qadec MA. Production ofProtaese by a locally isolated moold culture under lab conditions. Biotechnol. 2003; 2(1): $30-36$.

[24] Sathya R, Prada BB, Agayarkanni J, Polaniswamy M. production of milk clotting protease by a local isolate of mucor circinelloids under SFF using agro industrial wastes Biotechnology Bioprocess Engineering. 2009 ; 788 794.

[25] Lima CJB, Cortezi M, Lovaglio RB, Robiero EJ, Contiero J, Aurofo EU. production of Rennel in submerged fermentation with the filamentous fungus mucor muhei NRRL 3420 World Applied Science. 2008; 4(4): 578 585 .

[26] Areces LB, Biscogilo de jinenez, MJ, Parry MA, A frailet, ER Fernendez HM, Cascone O. purification and characterization of a milk-clothing protease from Mucor baciliformis App Biochem Biotechnol. 1992; 37: 283294.

[27] Dutt K, Meghwashi GK, Gupta P, Saxena RK. Role ofCasein induction and enhancement of production of bacterial milk ofproduction of bacterial milk clotting protease from an indigenously isolated Bacillus Subglutinans.

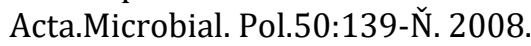

[28] Cavalcanti MTH, Teixeira MFs, Linafiho JL, Proto ALF. partial purification of new milk - clotting enzyme produced by no cardiopsis sp. Biores. Techn. 2004; 93: 29-38.

[29] Machalinski C, Pirpignani ML, Marino C, Mantegazza A. De, J Bonino MB. Structural aspect of Mucor bacilliformis proteinase, a new member of the aspartyl-Proteinase family. J. Biotechnol. 2006; 123.

[30] Vishwanatha KS, Appr RAU, Singh SA. Acid protease production by solid-state fermentation using Aespergilus Oryzae MTTC 5341: optimization of process parameters. Journal of Industrial Microbial Biotechnology. 2010; 37: 129-138.

[31] Hashem AM. purification and properties of a milk clotting production by penicillium oxacilicum Bio-resources Technology. 2000; 75: 219-222.

[32] Fernandez - Lahore HM, Audy RM, Fraile ER, Biscogliode M, Pirpignan L, Machalinski C, Cascone O. purification and characterization of an acid proteases from mesophillic mucor spp. Solid -state cultures. J. Rept Res. 1999; 53: 599-605.

[33] Sonal P. Function of rennin Enzymes plus the effect of Temperature on the enzyme. 2011.

[34] Rao MB, Tanksale A, Ghalge MS, Deshpande VV. Molecular And Biotechnological Aspect of Microbial Proteases. Microbiol. Mol. Biol. Rev. 1998; 62: 597-635.

[35] Kamini NRF, Fujii T, Kurosu T, Lefuji H. production, purificationand characterization of an extracellular lipase from the yeast cryptococcus sp. S-2 proc Biochem. 2000; 36: 317. 